(2018), 1 (1): 48-56

\title{
USING CHAIN CARD GAME TO IMPROVE THE WRITING SKILL OF THE SIXTH GRADE SD KARTIKA IV-1 MALANG
}

\author{
Iflinda Virgina Sutalistya \\ iieph78@gmail.com \\ SD Kartika IV-1 Malang
}

\begin{abstract}
Based on the implementation of Class Action Research (CAR) by using strategy of chain card game, there are detailed description for each cycle. In cycle I the students who has mastered the learning progress achieve $60 \%$ with the score average is 73,3 . For the learning activities there is 2 complete descriptors with the percentage of $85 \%$ and 3 incomplete descriptors with the percentage of $47,8 \%$. For creativity there are 2 complete descriptors with the percentage of $85 \%$ and 2 incomplete descriptors with the percentage of $55 \%$. For the Students' pleasant all off the descriptors are complete with the percentage of 93,3\%. The interactivity of the students show that all the descriptors are complete with the percentage of $85,5 \%$. There is an increasing of score that achieved by students who has mastered the learning. That is $80 \%$ with the average is 81,0 . For the learning activities all of the descriptors are complete with the percentage of $94 \%$. There is an increasing of $9,0 \%$. For the interactivity all of the descriptors are complete with percentage of $89,1 \%$. There is an increasing of $4,1 \%$. For the students' pleasant $100 \%$ are the descriptors are complete. There is an increasing of $6,7 \%$. For Interactivity, all of the descriptors also complete with the percentage of $96,7 \%$. There is an increasing of $11,2 \%$. Considering the data above, the implementation of chain card game can improve the students writing skill of sixth grade at SD Kartika IV-1 Malang
\end{abstract}

Key words: Writing, Simple Present, Sentence

CPendidikan Bahasa Inggris FPISH IKIP BU Malang

\section{INTRODUCTION}

Class Action Research activities are carried out because some of the problems faced both by teachers and by students in learning English. Generally accepted in the English language learning students must master the four language skills, namely: listening, speaking, reading and writing, but in this study only focused on problems that arise in writing activities, especially in making simple English sentences.

Data from the field indicate that the students' ability to make English sentences is very poor or still low; the average of value is 6.80 after the pretests conducted in SD Kartika IV-1 for the students' ability to make English sentences (TO).

Low students' ability in making English sentences is certainly influenced by several things, among others: lack of training provided by teachers, lack of variation teaching and learning activities in class and lack of tasks assigned by teachers. Therefore, this study aims to enhance students' ability in English sentences give depth views using the strategy Chain Card Game.

What is meant the ability to make a simple English sentence is the ability of students in expressing an idea in the form of sentences. In making the sentence needs to consider two things: The substance of the writing (ideas expressed) and the correct rules of language structure (grammatical forms and syntactic patterns). Make a sentence included in the activities for writing skill, because it also means to express ideas and communicate with others through the symbols of language (Harris, 1988).

Sentences that are made can be the most simple sentences containing only words in a sentence of two 
positions, namely the subject and verb ( $\mathrm{S}$ $+\mathrm{V})$; subject, verb and object $(\mathrm{S}+\mathrm{V}+$ $\mathrm{O})$ or the most complete sentences, i.e.: subject, verb, object, and information ( $\mathrm{S}$ $+\mathrm{V}+\mathrm{O}+\mathrm{Adv}$ ).

Games by Carrier (1982) have a very high value for foreign language teachers, because games provide opportunities for students to use a certain language skills with situations that are not too formal. Meanwhile, according to Hadfield (1984), the game is an activity that has a goal and element of fun. According to Frieda (2007), a teacher of UI Psychology Faculty in the event of the National Forum in Depok available in http://kategoriberita.net., when doing the game looks happy and laughing. Laugh before learning is not something bad. The atmosphere of joy actually uplifting. Bobbi DePorter and Mike Hernacki, in Quantum Learning, express joy with the awakening of positive emotions. Positive emotions will make the brain can work optimally (Hernowo, 2007:27). According to Meier if we want to Become Teachers and Capable in teaching More by Hernowo (2007), a fun learning is the learning that can bring changes to the learners themselves.

Chain Card Game is a game to help student to make a sentence easily. The players play just like playing cards. In this game, the player are assigned to arrange the cards have to be a sentence or playing cards to continue a sentence unfinished opposing players, and it can be at the beginning or the end of the card arrangement.

This game could be played by four players or more, with 60 sheets of card number English vocabulary, which is a sentence fragments that have been configured so that if the card is played correctly will form a correct English sentence.
The cards are made of cardboard with the size $5 \times 8 \mathrm{~cm}$. This size can be adjusted to the taste of the card maker. Based on the background in advance, the researcher wants to do a class action research with the title "Using chain Card Game to Improve the Writing Skill at Sixth Grade SD Kartika IV-1 Malang". The researcher wants to try to change long-standing tradition toward a newer, conducive and communicative.

\section{RESEARCH METHODOLOGY}

Time of the Research

The research was conducted for two months start from 1st week of February until 4th week of March

Place of the Research

The research located at SD Kartika IV-1 on Jalan Hamid Rusdi 100 Malang.

Object of the Research

As the object of the research are students of the Sixth grade SD Kartika IV-1 Malang which total 30 students consist of 17 male students and 13 female students.

\section{Research Design}

This research use Class Action Research which procedure of research are divided into cycle of activity refers to model adopted from Hopkins (1993:48), where each cycle consists of four main activities, those are planning, acting, observing and reflecting.

The design of Class Action Research follows the Lewin model that is interpreted by Kemmis (Rochiati Wiriatmaja):

Based on the design above, the phase of the study explained as follows: 1. Preliminary Study 
At this stage, researcher identifies the students' difficulties in understanding of making English sentences.

\section{Planning}

The problems will be overcome with determined steps of action planning that is compiling research instrument in the form:

\section{a. Lesson Plan (RPP)}

b. Make visual aid as cards with word using carton.

c. Student Activity Sheet /Student Work

Sheet.

d. Material of test

e. Questionnaires

f. Observation sheet

3. Acting

This stage is the implementation of action learning programs, making or collecting data from questionnaires, observation sheets and test results.

4. Observing, Reflecting, and Evaluating

This stage was conducted to collect data and analyze it then it can be taken conclusion from this research.

Research Instruments

To collect research data using instruments that include: worksheets, questionnaires, student observation sheet, and format of writing assessment.

Data Collection

In collecting the data, the researcher used observation, questionnaire, documentation and competency test.

Observation was done to observe the activities of students when they participated in the study by use of media chain card game to help students write a simple sentence. Observations aimed at observing the symptoms that appear in the learning process among other things, (1) the seriousness of the students when they follow the lesson. (2) the activity in the learning process, such as frequency of students asking, the frequency of students answering questions from the teacher (3) the creativity of students who appeared in the learning process such as creativity in the work, and the other opinion

Questionnaires is conducted to collect data about the impressions of students, about which they feel an atmosphere of learning during the learning process, about the complaints of students in the learning process, which are all very useful for subsequent learning process improvement.

Documentation conducted to collect data about various events in the learning process through photographs and documents in the form of students' work.

Tests used to determine the extent to which students can write sentence properly by using the chain card game.

\section{Data Analysis}

The data has been collected will be analyzed descriptively, both quantitative and qualitative descriptive. The detailed data analysis methods are as follows:

1. Observation data to determine how much students feel happy to follow the learning activities through a media chain card game, which obtained from observations by teachers and records observation format. Results were analyzed the percentage of observations that the results were compared between cycle I and cycle II.

2. Learning outcomes data collected through the correction of the test after following the learning activities through a media of chain card game. These results are analyzed by the percentage and looking for average 
values and compared between cycle I and cycle II.

The analysis of students' learning progress is shown by the percentage with a following formula:

$$
\text { Percentage }(\mathrm{P})=\quad \text { Frequency }
$$

students (n)

Amount of

The mean of students writing achievement shown by the following formula:

$$
\begin{aligned}
& M=\quad \sum x(f) \\
& M=\text { Mean } \\
& X=\text { score } \\
& F=\text { frequency }
\end{aligned}
$$

3. To complement the results of research carried out questionnaires to determine student perceptions about the application of learning through the media of chain card game. Analyzed the questionnaire results reached by the percentage of each item questionnaire.

\section{Indicator of Success}

Based on the results obtained from the pretest and post test that reflects students' understanding in making a sentence that learned according to the value obtained by each student.

Minimum $75 \%$ of the students has got value $75(\mathrm{KKM}=75)$.

Minimum $80 \%$ of the total number of students has reached the mastery learning 75 .

Minimum $75 \%$ of the total number of students has motivated to learn using instructional media of chain card game.

\section{DISCUSSION}

Action research with the implementation of the chain card games strategy which implemented in the sixth grade SD Kartika IV-1 Malang intent to making through two cycles, and the detailed descriptions of the following actions:

Cycle One (I)

1. Planning

Prepared the action plan including:

a. The teachers make lesson plan associated with the strategy will be implemented.

b. Prepare the media of chain card game

c. Prepare the worksheets and material of test I

d. Arrange observation sheet to know the process of writing students' learning takes place through chain card game

e. Implement appropriate learning through chain card game based on the lesson plan.

2. Implementation of Action

Providing action with Chain Card Game performed at the time of writing skills, in detail the course of implementation as follows:

a. The first meeting frequently is started with asked questions about the theme of writing and makes an agreement about the themes that will be discussed. Debriefing process produced an agreement that students will learn about the theme of tourist object.

b. The teacher gives an explanation of a concept of writing. Starting with explaining how to arrange the simple sentence determines the subject, predicate and object and explains that in writing a coherent and systematically is cultivated.

c. Teacher asks to the students to make a group into five which consist of six students each group.

d. To facilitate the students, the teacher gives the chain card media to help them and explain of the steps and rules of the game. 
e. Teachers distribute Student Activity Sheet (LKS) to the group.

f. Teacher asks students to begin playing, and then asked the representatives of the group to arrange the cards into a good sentence and write on the student activity sheet.

g. Then held a discussion on the results of the exercise that has been done. Discussion of the results of exercises conducted by students classically corrected together.

The implementation of Chain Card Game in the first cycle was given for two meetings; the subject is about tourist object and sub of tourist object in Malang. During the treatment progresses, the collaborator observed the learning progress using observation sheets and record everything that happens during the learning progress. The findings obtained are recorded in field notes sheet. After two meetings left, perform the test I ( $\mathrm{t}-1)$ to measure students' skills in making English sentences, and as data for comparison with initial test data (to) so that researchers can find all the developments that have occurred.

\section{Observation}

Research data that have been recorded is related the improvement of writing comprehension and the result of observation such as activity, creativity, pleasure and interactivity. The improvement of comprehension is obtained from the competency test. And activity, creativity, pleasure, interactivity in the class is obtained from the observation result. All data is recorded during the learning progress.

The student who has mastered the learning progress are $60 \%$ and the score average of the class is 73,3 in the cycle I.

The standard score of mastering learning is 75 .
Learning Activities

There are 3 incomplete descriptors with the percentage of $47,8 \%$ and there are 2 complete descriptors with the percentage of $85.0 \%$. So that is needed to be increase in the furthermore cycle.

Creativity

There are 2 incomplete descriptors with the percentage of $55,0 \%$ and 2 complete descriptors with the percentage of with the percentage of $85 \%$ and need to be increase in the furthermore cycle.

Students' Pleasant

The students' pleasant descriptors are complete with the percentage of $93,3 \%$.

Interactivity

the descriptor of interactivity are complete with the percentage of $85,5 \%$.

\section{Reflection}

For the reflection phase will be stated some of term about the result of the implementation of learning progress, as follows :

a. The implementation of chain card game has conduct good enough, but it does not obtain an optimal result yet, so it need do the improvement furthermore

b. Teacher has implement the lesson plan correctly and show all the indicators

c. At the discussion or team work, most of students has done all the task properly but there is a less of students inactive and rely on their friend to do the task

d. The students still have less of creativity in show their ideas 
e. Most of students has shown happy $\mathrm{n}$ joy in learning using chain card game but there is some of student are unserious so that disturb another students.

f. Based on the observation sheet, the activity, creativity and interaction need to be increased.

g. Based on the result of competency test show that the students' comprehension is needed to be increased.

To reduce the problem above, the second cycle of action, among others: to give understanding to the students that they play in order to learn, arrange a place to play better, give reward to the best students, adding cards to 80 cards, and add time to discussion of sentences that are formed during a game in progress.

\section{Cycle Two (II)}

\section{Planning}

Before the second cycle was conducted, there are some things that need to be prepared, among others:

a. The teachers make lesson plan associated with the strategy will be implemented.

b. Prepare the media of chain card game

c. Prepare the worksheets and material of test II

d. Arrange observation sheet to know the process of writing students' learning takes place through chain card game and interview guide

e. Implement appropriate learning through chain card game based on the lesson plan.

2. Implementation of Action

Providing action with Chain Card Game performed at the time of writing skills, in detail the implementation of course as follows:

a. Teacher give understanding to the students to play quietly, b. Arranging a place to play better with take place of study outdoor

c. Explain the steps clearly

d. Adding the amount of card to be 80 cards per set

e. Implementation the learning process based on the lesson plan

f. Teachers distribute Student Activity Sheet (LKS) to the group.

g. Teacher asks students to begin playing, by compete two group arrange the sentence and take turn each member of the group. The winner of the competition is the group who can arrange sentence correctly and fast based on the time that has been determined.

h. Then held a discussion on the results of the exercise that has been done. Discussion of the results of exercises conducted by students classically corrected together.

The implementation of Chain Card Game in the cycle two was given for two meetings, the subject is about Weather and Seasons. After two meetings, then conducted tests II ( $t-2)$ to be compared with the results of test I ( $t-1)$ to obtain certainly whether treatment on the second cycle can enhance students' skills in writing English.

3. Observation

To know the further effectiveness of chain card game in improving students' skill in making English sentences, then held test II (t-2), get the data.

The student who has mastered the learning progress is $80 \%$ and the score average of the class is 81,0 in the cycle II.

The standard score of mastering learning is 75 .

The students who achieve the score more than 75 reach $80 \%$ and less than 75 reach $20 \%$ in the cycle II. learning activities all of the descriptors are complete with the percentage of $94 \%$. 
The descriptors of students' creativity are complete with the percentage of $89,1 \%$.

The descriptor of students' pleasant is complete with the percentage of $100 \%$.

The students' interactivity, there is 1 incomplete descriptor with the percentage of $66,6 \%$, and 2 complete descriptors with the percentage of 96.7 $\%$.

\section{Reflection}

Based on observations at the end of the second cycle has obtained a description that students already feel happy to follow the learning process. Students more easily learn the English language sentence. This is evidenced by the increasing value of each student writing. Based on the questionnaire were also detected that most students are motivated and increase confidence by writing a learning activity using the chain card game. With the appreciation of students motivated to actively ask questions and put forward opinions. With these data it was felt that the research objectives have been achieved at the second cycle. Therefore, the researchers looked at the research end of this class action in the second cycle.

\section{Discussion}

Based on data analysis has been done, it can be concluded that the Chain Strategy Game Card can be used to enhance students' skills in making English sentences. This strategy can also improve students' passion to learn English.

In accordance with the statement of the problem and based on data collection and data analysis, can discuss two things:

1. Increasing of students' activity of fun when students follow the learning activities using chain card game. The atmosphere can make the students relaxed and pleasant. Locations outside allows the students are not tense and can be enjoyed in comfort. When discussing the results appeared most students active by raised a hand sign that they dared to put forward opinions and ideas.

2. The improving of students result after learning process.

Result of data analysis showed that it increases from the cycle I and cycle II. With the end of cycle II, the researcher felt that the application of instructional media of chain card game can improve activities and student learning outcome. This was evidenced by increased percentage of the activity and students learning outcome as reflected in the above discussion.

\section{CONCLUSION AND SUGGESTION}

\section{Conclusion}

The conclusion that can be drawn from this class action research is :

1. The implementation of media chain card game can improve the student mastery learning, It is prove by score who students get in the cycle I which more than 75 is $60,0 \%$ and in the cycle II is $80,0 \%$. There is an increasing of $20 \%$ for the students who get score more than 75 .

2. The average of score of competency test in cycle I is 73,3 and in the cycle II is 81,0. There is an increasing 7,7, and it is prove that the implementation of media chain card game can improve the students learning outcomes.

3. Implementation chain card game can motivate the students to learn English writing. For the learning activities in the cycle I there is 3 incomplete descriptors with the percentage of $47,8 \%$ and 2 complete 
descriptors with the percentage of $85,0 \%$. In the cycle II all of descriptors are complete with the percentage of $94 \%$. There is $9 \%$ increasing in the cycle II. For the Interactivity of students there is 2 incomplete descriptors with the percentage of $55,0 \%$ and 2 complete descriptors with the percentage of $85 \%$. In the cycle II all of the descriptors are complete with the percentage of $89,1 \%$. There is an increasing $4.1 \%$ in the cycle II. For the students' pleasant all of the descriptors are complete with the percentage of $93,3 \%$. In the cycle II all of the descriptors also complete with the percentage of $100 \%$. There is an increasing $6,7 \%$ in the cycle II. For the Interactivity, all of the descriptors are complete with the percentage of $85,5 \%$ and all of descriptors also complete in the cycle II with the percentage of $96,7 \%$. There is an increasing $11,2 \%$ in the cycle II.

\section{Suggestion}

Considering the importance of developing innovative teaching strategies for learning and meaningful learning result, here are some suggestions:

1. Media of chain cards game can be tested for English language learning concepts.

2. Media of chain card game can be modified again in accordance with the need of school condition, characteristic of the subject and grade levels.

\section{REFERENCES}

Carrier, M. 1982. Game and Activities for the Language Learner. London: Harrap.

Deporter, B., Reardon, M. \& SingerNourie, S. 2001. Quantum Teaching. Bandung: Kaiffa.

Harfield, J. 1984. Elementary Communication Games. Thomas Nelson and Son Ltd.
Harris, D.R 1988. Testing English as a Second. New york: McGraw-Hill Book Company.

Brown, Douglas H. 2000. Principles of Language Learning and Teaching (4 th Edition). New York: Longman Inc.

Cahyono, Bambang Yudi. 1997. Pengajaran Bahasa Inggris: Teknik, Strategi, dan Hasil Penelitian. Malang: IKIP Malang.

Celce, Marianne and Murcia. 2001. Teaching English as a Second or Foreign Language. Massachusetts: Newbury House Publisher Inc.

Fachrurrazy. 2002. Teaching English as a Foreign Language. Unpublished. Malang: The State University of Malang.

Johnson, Burke, et. al. 2004. Educational Research: Quantitative, Qualitative, and Mixed Approaches, 2 nd Edition. New York: Pearson Education, Inc.

Lodico, Marguerite G., et. al. 2006. Methods in Educational Research, from Theory to Practice. Australia: John Wiley and Sons Inc.

Setiyadi, Ag. Bambang. 2006. Teaching English as a Foreign Language. Yogyakarta: Graha Ilmu.

Wikipedia, the Free Encyclopedia. 2007. Teaching English as a Foreign Language.

http://en.wikipedia.org/wiki/Teachi ng English as a foreign language. Accessed on July 20, 2007. 
Best, John W. and Kahn, James V. (1989). Research in Education, New Delhi: Prentice-Hall of India.

Kemmis, S and MC.Taggard R, 1988.

The Action Research Planner, Deaki University.

Arikunto, Suharsimi, Suhardjono \& Supardi.2007. Penelitian Tindakan Kelas, Jakarta: Bumi Aksara

Mulyasa, E. 2009. Praktik Penelitian Tindakan Kelas, Bandung: Rosdakarya

Depdiknas. 2005. Panduan Penyusunan Usulan dan Laporan Penelitian Tindakan Kelas. Depdiknas: Dirjen Dikti

Fraenkel and Wallen. 1993. How to Design and Evaluate Research in Education, New York: McGrawHill Inc.

Sa'dun Akbar. 2002. Penelitian Tindakan Kelas: Filosofi, Metodologi \& Implementasi, Yogyakarta: Cipta Media

Sa'dun Akbar. 2009. Prosedur Penyusunan Laporan dan Artikel, Yogyakarta: Media Aksara 